\title{
Endoplasmic reticulum stress in chondrodysplasias caused by mutations in collagen types II and $X$
}

\author{
Katarzyna Gawron ${ }^{1}$
}

Received: 31 January 2016 /Revised: 1 July 2016 / Accepted: 5 July 2016 / Published online: 15 August 2016

(C) The Author(s) 2016. This article is published with open access at Springerlink.com

\begin{abstract}
The endoplasmic reticulum is primarily recognized as the site of synthesis and folding of secreted, membranebound, and some organelle-targeted proteins. An imbalance between the load of unfolded proteins and the processing capacity in endoplasmic reticulum leads to the accumulation of unfolded or misfolded proteins and endoplasmic reticulum stress, which is a hallmark of a number of storage diseases, including neurodegenerative diseases, a number of metabolic diseases, and cancer. Moreover, its contribution as a novel mechanistic paradigm in genetic skeletal diseases associated with abnormalities of the growth plates and dwarfism is considered. In this review, I discuss the mechanistic significance of endoplasmic reticulum stress, abnormal folding, and intracellular retention of mutant collagen types II and X in certain variants of skeletal chondrodysplasia.
\end{abstract}

Keywords Endoplasmic reticulum stress $\cdot$ Unfolded protein response $\cdot$ Mutation $\cdot$ Collagen $\cdot$ Chondrodysplasia . Mechanism

\section{Introduction}

The endoplasmic reticulum (ER) is an eukaryotic organelle responsible for synthesis, folding, trafficking, and sorting of proteins. It also plays an important role in lipid and steroid synthesis as well as calcium homeostasis (Engin and Hotamisligil 2010; Hosoi and Ozawa 2009). An imbalance

Katarzyna Gawron

katarzyna.gawron@uj.edu.pl

1 Microbiology Department, Faculty of Biochemistry, Biophysics and Biotechnology, Jagiellonian University, Gronostajowa 7, 30-387 Krakow, Poland between the load of unfolded proteins and the processing capacity in ER leads to the accumulation of unfolded or misfolded proteins and ER stress (Ron and Walter 2007; Schröder and Kaufman 2005; Sano and Reed 2013). To alleviate accumulation of unfolded proteins, the process being toxic to cells, ER triggers an evolutionarily conserved signaling cascade, named unfolded protein response (UPR) (Engin and Hotamisligil 2010; Schröder and Kaufman 2005; Tsuru et al. 2016; Lin et al. 2008). Adaptation and restoration of ER function through UPR signaling comprise translational attenuation of global protein synthesis, upregulation of ER chaperones and prevention from trafficking (to the proper subcellular localizations), as well as degradation of unstable or partially folded mutant proteins by an endoplasmic reticulumassociated degradation (ERAD) system (Engin and Hotamisligil 2010; Hosoi and Ozawa 2009; Ron and Walter 2007; Schröder and Kaufman 2005; Bernales et al. 2006). If ER stress is excessive or prolonged and cannot be resolved, signaling switches from prosurvival to proapoptotic (Hosoi and Ozawa 2009; Szegezdi et al. 2006). ER stress and UPR are critical for the normal cellular homeostasis and development of the organism and are also known to play major roles in the pathogenesis of many diseases such as neurodegenerative (Uehara et al. 2006; Hoozemans et al. 2007; Perri et al. 2016) and cardiovascular (Minamino et al. 2010; Kassan et al. 2012) diseases, diabetes (Basha et al. 2012), obesity (Hosoi et al. 2008), inflammation (Ha et al. 2015), and cancer (Suh et al. 2012; Chhabra et al. 2015; Lin et al. 2008; Mahdi et al. 2016; Yoshida 2007a). In recent years, accumulating evidence indicates that abnormal folding and accumulation of structural proteins that are produced to fulfil their physiological function in the extracellular space of tissues may lead to ER stress and induction of a wide range of systemic diseases. For instance, several reports linked ER stress to mutations in collagen type II that induce various forms of spondyloepiphyseal dysplasia 
(SED) (Chung et al. 2009; Okada et al. 2015; Liang et al. 2014). Other studies highlight the role of ER stress in the pathogenesis of metaphyseal (chondro) dysplasia, Schmid type (MCDS), a disorder caused by mutations in the collagen type $\mathrm{X}$, characterized by expansion of the hypertrophic zone of the growth plate resulting in dwarfism (Rajpar et al. 2009; Ho et al. 2007; Mäkitie et al. 2010). Another studies point out the crucial role of ER stress in diseases caused by mutations in collagen type VI genes that lead to the mild to severe phenotype of myopathies, including Ullrich congenital muscular dystrophy (UCMD) and Bethlem myopathy (BM) (De Palma et al. 2014), or mutations in collagen type IV genes (COL4A3/COL4A4/COL4A5) that contribute to the pathogenesis of thin-basement-membrane nephropathy (TBMN) and Alport syndrome (AS) (Pieri et al. 2014) and cataract development (Firtina et al. 2009). Succeeding examples comprise ocular dysgenesis, myopathy, brain malformations, cerebrovascular disease, and cerebral hemorrhages, all caused by mutations in collagen type IV (COL4A1/COL4A2) (Kuo et al. 2014; Jeanne et al. 2012; Verbeek et al. 2012; Volonghi et al. 2010; Gould et al. 2007). Moreover, accumulating evidence shows an association between mutations in genes encoding proteins involved in type I procollagen processing or chaperoning and pathogenesis of recessive variants of osteogenesis imperfecta (OI), while dysregulation of molecular chaperones is implicated in ER stress in severe forms of osteoarthritis (OA) (Lisse et al. 2008; Kelley et al. 2011; Marini et al. 2010; Bodian et al. 2009; Symoens et al. 2013; Nugent et al. 2009; Takada et al. 2011).

In this review, basic mechanisms of ER stress and its significance in certain variants of chondrodysplasia caused by mutations in collagen types II and X are discussed.

\section{Endoplasmic reticulum stress}

The endoplasmic reticulum is a membranous organelle and is one of the major compartments for the biosynthesis, maturation, and folding of proteins. The specialized intra-ER environment contains several factors that are required for the formation of disulfide bonds and for optimal protein folding, including ATP, $\mathrm{Ca}^{2+}$, and unique oxidizing conditions. The accuracy of protein folding is also monitored by $\mathrm{Ca}^{2+}$-dependent molecular chaperones, such as glucose-regulated protein $78 \mathrm{kDa}(\mathrm{Grp} 78 / \mathrm{BiP})$, glucose-regulated protein $94 \mathrm{kDa}$ (Grp94), calreticulin (CRT), and calnexin (CNX) which stabilize the protein folding intermediates and prevent the aggregation of proteins in the ER (Szegezdi et al. 2006; Anelli and Sitia 2008; Kim et al. 2008; Hetz 2012; Mahdi et al. 2016). The physiological state of the ER is challenged when the influx of the nascent unfolded or misfolded polypeptides exceeds the processing capacity of the ER (Schröder and Kaufman 2005; Sano and Reed 2013). Correct protein folding may fail as a result of gene mutations, RNA modifications, amino acid misincorporation during translation, or unequal synthesis of individual subunits of multisubunit protein species. Furthermore, posttranslational modifications can be caused by changes in $\mathrm{pH}$, temperature, ionic strength, and oxidative and other stresses (Kim et al. 2008; Hetz 2012; Schröder 2008). The unfolded/misfolded proteins expose hydrophobic domains that are normally hidden within the correctly folded polypeptide's structure. The interaction between such inappropriately folded proteins may lead to their accumulation within the cells. In turn, aggregates may interfere with cellular functions and are potentially cytotoxic. Three hypotheses have been proposed to explain cytotoxic mechanisms: (i) the channel hypothesis suggesting that ring-shaped oligomers form pores in cellular membranes, (ii) misfolded proteins lead to dysfunction of normal proteins with which they interact, and (iii) misfolding proteins may deplete components of the quality control system, which consists of chaperone and degradation systems, thereby reducing their functionality (Barral et al. 2004). To restore cellular integrity and homeostasis, cells activate evolutionarily conserved adaptive response, called UPR, that consists of several quality control systems (Schröder and Kaufman 2005; Lin et al. 2008; Szegezdi et al. 2006; Schröder 2008) that act in concert for (i) inhibiting general protein translation, (ii) activating the signaling pathways that lead to expression of molecular chaperones and increasing folding capacity, and (iii) promoting the degradation of misfolded proteins and reducing aggregation (Engin and Hotamisligil 2010; Anelli and Sitia 2008; Kim et al. 2008; Hetz 2012). UPR is mediated through activation of three ER transmembrane receptors: inositol-requiring enzyme 1 (IRE1), activating transcription factor 6 (ATF6), and protein kinase RNA-like endoplasmic reticulum kinase (PERK). Under physiological conditions, all three factors related to ER stress are maintained in inactive form through their association with Grp78 (Anelli and Sitia 2008). Upon accumulation of unfolded proteins in the lumen of the ER, Grp78 dissociates from IRE1, ATF6, and PERK, which leads to their activation and assistance in folding processes (Szegezdi et al. 2006; Anelli and Sitia 2008; Shen et al. 2002; Rutkowski and Kaufman 2004). PERK is a type 1 transmembrane protein kinase residing in the ER which is activated in response to perturbation of protein folding and constitutes a signal transducer of the earliest phase of stress response (Liu et al. 2016). UPR first alleviates the ER stress by diminishing the overall protein load via PERK-mediated phosphorylation of the $\alpha$ subunit of eukaryotic translation initiation factor 2 (eIF2 $\alpha$ ) (Mahdi et al. 2016; Liu et al. 2016; Joshi et al. 2013; Zhang et al. 2013). In turn, the decrease in eIF 2 activity promotes the translation of activating transcription factor 4 (ATF4) resulting in the activation of CCAAT/enhancer binding protein (C/EBP) homologous protein (CHOP) production, which promotes ER stress-induced apoptosis (Ron and Walter 2007; 
Walter and Ron 2011; Fawcett et al. 1999; Jiang et al. 2004). ATF6 is a basic leucine zipper (bZIP) transcription factor that upon dissociation of Grp78 translocates to the Golgi complex, in which it undergoes proteolytic cleavage by the serine protease (S1P) and the metalloprotease (S2P) (sites 1 and 2, respectively) (Shen et al. 2002; Zhang et al. 2013; Nadanaka et al. 2006). The cleaved $50 \mathrm{kDa}$ cytoplasmic bZIP-containing fragment translocates to the nucleus, where it binds to the ER stress response element (ERSE) and activates genes involved in the adaptive stress response, i.e., Grp78, CHOP, and X-box binding protein 1 (XBP1) (Anelli and Sitia 2008; Nadanaka et al. 2006; Brown et al. 2000). It has been shown that cell- or tissue-specific UPR may exist under ER stress; for example, cAMP response element binding protein $\mathrm{H}(\mathrm{CREBH})$ has been identified as a regulated intramembrane proteolysis (RIP)-regulated liver-specific transcription factor that is cleaved upon ER stress (Zhang et al. 2006) while old astrocyte specifically induced substance (OASIS), which is similar to the ATF6 family, has been identified as a transducer of ER stress in astrocytes (Kondo et al. 2005). IRE1 is a type 1 transmembrane serine/threonine receptor protein kinase which is activated via homodimerization and transautophosphorylation upon dissociation from Grp78 (Hosoi and Ozawa 2009; Zhang et al. 2013). The activated domain of IRE1 acts like a nuclease and catalyzes the removal of a small intron from XBP1 messenger RNA (mRNA) (Zhang et al. 2013; Yoshida 2007b). This splicing creates a translational frameshift in XBP1 to produce an active transcription factor which directly binds to the ERSE and the UPR element (UPRE), leading to the upregulation of genes such as ER chaperones, e.g., Grp78 gene (HSPA5) (Hosoi and Ozawa 2009; Suh et al. 2012; Anelli and Sitia 2008; Shen et al. 2002) (Fig. 1).

Protein quality control primarily promotes cell survival and the maintenance of cellular homeostasis by switching on several pathways of the adaptive response. One of the central ER

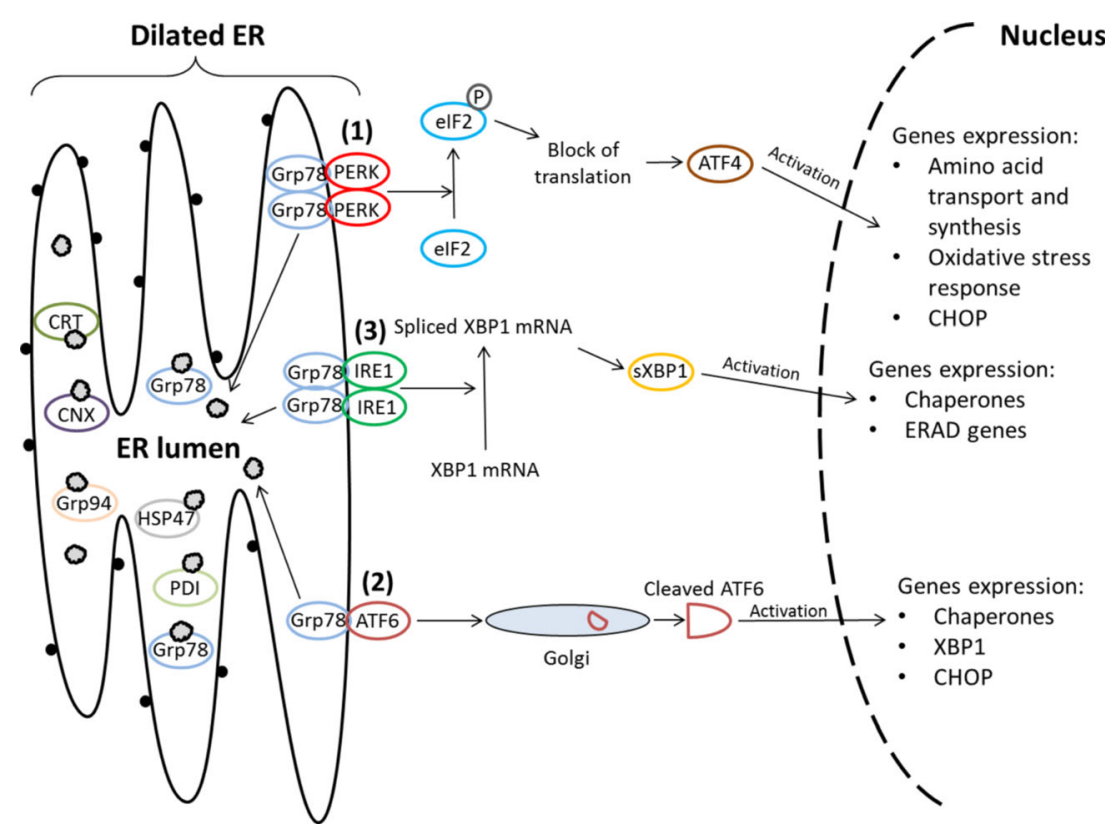

Fig. 1 Endoplasmic reticulum signaling triggers unfolded protein response. Under physiological conditions, glucose-regulated protein $78 \mathrm{kDa}(\mathrm{Grp} 78 / \mathrm{BiP})$, protein disulfide isomerase (PDI), heat shock protein 47 (HSP47), and other molecular chaperones are present in the lumen of endoplasmic reticulum (ER). Additionally, Grp78 binds the ER luminal domains of the three ER stress receptors, i.e., protein kinase RNA-like endoplasmic reticulum kinase (PERK), activating transcription factor 6 (ATF6), and inositol-requiring enzyme 1 (IRE1). Accumulation of unfolded proteins in the ER, e.g., as a result of mutation in the collagen gene, induces sequential dissociation of Grp78 from PERK (1), ATF6 (2), and IRE1 (3), respectively, and their activation. Dissociated Grp78 molecules and other chaperones are mobilized to form complexes with unfolded proteins aggregated in the ER. Activated PERK (via dimerization and autophosphorylation) phosphorylates eukaryotic initiation factor $2 \alpha$ $(\mathrm{eIF} 2 \alpha)$. This phosphorylation suppresses general protein synthesis, thus decreasing the entry of newly synthesized proteins into the ER and enabling translation of ATF4. ATF4 translocates to the nucleus and induces the transcription of genes required to restore ER homeostasis including that for CCAAT/enhancer binding protein homologous protein (CHOP). ATF6 is activated by limited proteolysis after its translocation from the ER to the Golgi apparatus. It is cleaved by site 1 and site 2 proteases (S1P, $\mathrm{S} 2 \mathrm{P})$ releasing the cytoplasmic $50 \mathrm{kDa}$ domain $\left(\mathrm{ATF}_{50}\right)$ which is an active transcription factor. ATF $6_{50}$ regulates the expression of genes involved in the unfolded protein response (UPR), including chaperones, CHOP, and X-box binding protein 1 (XBP1). Additionally, the activation of XBP1 is carried out by IRE1. Activated IRE1 produces an unconventional splice in cytoplasmic XBP1 mRNA. Spliced XBP1 protein (sXBP1) translocates to the nucleus and upregulates the transcription of genes encoding chaperones to increase the protein folding capacity of the ER and genes controlling the endoplasmic reticulum-associated degradation (ERAD) system, a mechanism by which misfolded protein is retrotranslocated into the cytoplasm and degraded in the proteasome. This complex action aims to restore ER homeostasis by blocking unfolded protein aggregation, inducing degradation of aggregated proteins and enhancing folding capacity 
stress defense strategies is to upregulate coordinately its chaperoning capacity. Chaperones are specialized proteins that play a key role in cellular homeostasis by assisting in protein folding, assembly of the macromolecular complexes, protein transport, and cellular signaling (Ullman et al. 2008). In the ER, the main function of chaperones is to prevent inappropriate aggregation of nascent peptide chains during protein synthesis. Chaperones bind to and stabilize exposed hydrophobic domains of target proteins and promote proper folding of newly synthesized proteins. This process involves cycles of controlled binding and release of target polypeptides (Horwich 2004; Chaudhuri and Paul 2006). While some chaperones non-specifically interact with a wide variety of polypeptides, others are restricted to specific subsets or even individual proteins. Chaperones are expressed and maintained at steady levels in unstressed cell; however, their expression is highly upregulated during stress conditions. Dysregulated chaperonic activity results in unfolded, misfolded, or aggregated proteins that will eventually be targeted to degradation pathways or accumulate in cells, leading to impairment of function and eventually contributing to various diseases. Apart from their critical role in protein folding, chaperones also function as signal-transducing molecules by affecting the transition between active and inactive states of signaling molecules, changing their subcellular localization or affecting protein-protein interactions (Engin and Hotamisligil 2010).
Interestingly, chaperones are able to distinguish between the native and non-native states of targeted proteins, but how they discriminate between correctly and incorrectly folded proteins and how they target the latter for degradation are yet to be explored (Vembar and Brodsky 2008). Apart from molecular chaperones, the ubiquitin proteasome pathway (UPP) is referred to as the second part of a protein quality control system (PQCS) and plays a critical role in cell function and survival. It has been shown that disturbance in or impairment of the UPP, which may be induced by the accumulation of misfolded proteins in the ER or loss of function of the enzymes involved in the ubiquitin conjugation and deconjugation pathway, leads to altered UPP function, which positively affects the accumulation of protein aggregates in the cell. The formation of oligomers and aggregates occurs in the cell when a critical concentration of misfolded protein is reached. Aggregated proteins inside the cell often lead to the formation of "an amyloidlike structure," which eventually causes different types of degenerative disorders and, ultimately, cell death (Anelli and Sitia 2008). Finally, when correct folding is impossible and degradation by the UPP is insufficient, then the UPR switches from being prosurvival to proapoptotic (Engin and Hotamisligil 2010; Schröder and Kaufman 2005). Typically, excessive ER stress leads to apoptosis via an increase in the expression of CHOP or by inducing caspase-dependent apoptosis (Lin et al. 2008; Szegezdi et al. 2006; Chiribau et al.

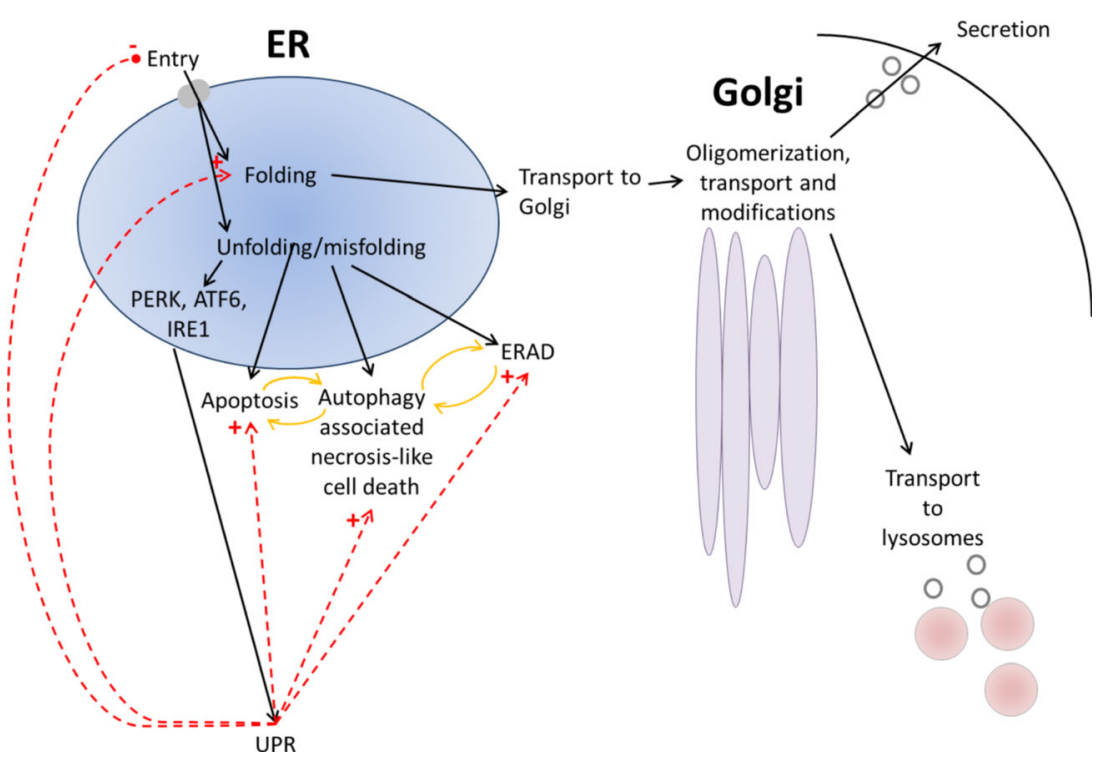

Fig. 2 Quality control interplay in the "ER-Golgi-lysosomes/ extracellular space axis." Extracellular space proteins, e.g., collagens, are synthesized by ribosomes and translocated into the endoplasmic reticulum (ER). In the ER, proteins accomplish their native form (folding, assembling) under strict quality control mechanisms. Appropriate folding/structure of the proteins enables their transport and modification in the Golgi, followed by transport to the extracellular space and/or to lysosomes. Accelerated aggregation of unfolded/misfolded proteins which overload the folding capacity within the ER induces the ER stress sensors, i.e., protein kinase RNA-like endoplasmic reticulum kinase (PERK), activating transcription factor 6 (ATF6), and inositol- requiring enzyme 1 (IRE1) which further activate the unfolded protein response (UPR) signaling. Unfolded/misfolded proteins are retained and directed to degradation by endoplasmic reticulum-associated degradation (ERAD) system, apoptosis, or autophagy (reciprocal regulation, yellow arrows). Under the quality control mechanisms, the ER stress aims to restore the homeostasis within ER through regulation of protein entry into the ER, folding, and degradation. Black arrows show the alternative pathways of the ER-Golgi-lysosomes/extracellular space axis depending on the proper folding, unfolding, or misfolding of protein. Red, intermittent arrows depict homeostatic control pathways (plus sign stimulatory, minus sign inhibitory) 
2010). In certain circumstances when excessive ER stress fails to induce apoptosis, autophagy might also serve as an alternative route leading to cell death and necrosis (Szegezdi et al. 2006; Suh et al. 2012; Ullman et al. 2008) (Fig. 2).

\section{Endoplasmic reticulum stress and the diseases}

Many inherited disorders of connective tissue are caused by mutations in genes encoding structural components of the extracellular matrix $(\mathrm{ECM})$ or enzymes that participate in their posttranslational modifications and assembly. Often the mutations interfere with ECM protein folding and inhibit their secretion from the cell resulting in disruption of their function in connective tissue. Therefore, although the prevailing paradigm for inherited diseases of the ECM has involved predominantly extracellular molecular pathology, more recently, an increasing number of reports have shown that intracellular processes may affect the pathology of these conditions as well (Bateman et al. 2009).

Up to now, the role of ER stress and the activation of pathways leading to UPR have been intensively investigated in a number of neurodegenerative disorders, e.g., Alzheimer's and Parkinson's diseases (Perri et al. 2016; Uehara et al. 2006; Hoozemans et al. 2007; Ron et al. 2010), cancer (Chhabra et al. 2015; Suh et al. 2012; Ha et al. 2015), and chronic metabolic diseases such as obesity, insulin resistance, and type 2 diabetes (Hotamisligil 2010); in a number of lysosomal storage disorders, e.g., Fabry's and Gaucher's diseases (Yam et al. 2006; Maor et al. 2013; Ron et al. 2010); and in the pathology of diseases involving professional secretory tissues such as cystic fibrosis and $\alpha 1$-antitrypsin deficiency (Bartoszewski et al. 2011; Alam et al. 2014). Recent reports investigating effects of mutations on assembly and secretion of several ECM components suggest that multiple outcomes such as misfolding and intracellular accumulation of mutant ECM proteins may result from induction of ER stress (Chung et al. 2009; Liang et al. 2014; Rajpar et al. 2009; Pieri et al. 2014; Firtina et al. 2009; Gould et al. 2007; Nugent et al. 2009; Bateman et al. 2009; Boot-Handford and Briggs 2010; Yang et al. 2005).

\section{Mutations leading to cartilage pathology}

Cartilage is a connective tissue that serves multiple functions during embryonic development and in postnatal life. It is composed of collagenous proteins, mainly type II in hyaline cartilage, collagen type X, glycoproteins, proteoglycans, and glycosaminoglycans (Sophia Fox et al. 2009; Yang et al. 2005). The chondrocyte, the only resident cell found in cartilage, proliferates and secretes ECM forming the cartilage template of the skeleton during development. In adults, chondrocytic cells produce and maintain ECM that participates in growth, mechanical support, and function of diarthrodial joints between bones (Sophia Fox et al. 2009; Mackie et al. 2011). Longitudinal bone growth is dependent on the strict temporal regulation and control of chondrocyte proliferation, differentiation, hypertrophy, apoptosis, and vascular invasion within the growth plate by a complex network of regulatory molecules and interactions of cells and ECM (Mackie et al. 2011; Karsenty 2008; Karsenty et al. 2009). Until now, over 400 skeletal disorders have been described, and several are caused by mutations in cartilage ECM genes that are critical to endochondral ossification (Warman et al. 2011). Although individually rare, they cause a significant impact on the quality of life for patients suffering from skeletal abnormalities. Genes encoding cartilage ECM proteins affected by mutations which disrupt growth plate differentiation comprise collagen types II, IX, X, and XI; aggrecan; cartilage oligomeric matrix protein (COMP); and matrilin 3 (Hintze et al. 2008; Chung et al. 2009; Liang et al. 2014; Ho et al. 2007; Mäkitie et al. 2010; Kuivaniemi et al. 1997; Warman et al. 2011; Bateman et al. 2009; Boot-Handford and Briggs 2010; Yang et al. 2005; Briggs et al. 2015). The list of collagenopathies associated with mutations in collagen types II and $\mathrm{X}$ is presented in Table 1.

\section{Mutations in collagen type II}

Collagen II, a main structural protein of cartilaginous tissues, is first synthesized as procollagen, characterized by the presence of an extended triple-helical domain flanked by the globular N-terminal and C-terminal propeptides (Arnold and Fertala 2013). Biosynthesis of procollagen molecules is a complex process that involves posttranslational modifications of the nascent pro- $\alpha$ chains. These modifications include hydroxylation of proline residues and lysine residues by prolyl-4 hydroxylase ( $\mathrm{P} 4 \mathrm{H})$ and lysyl hydroxylase ( $\mathrm{LH})$, respectively. In turn, the posttranslational modifications and formation of the triple-helical structure are controlled by molecular chaperones that belong to the group of proteins residing in the ER, which includes heat shock protein 47 (HSP47), Grp78, and protein disulfide isomerase (PDI), amongst which the latter enzyme also acts as the $\beta$ subunit of the $\alpha \alpha / \beta \beta$ tetramer that constitutes functional P4H (Chung et al. 2009; Ono et al. 2012; Patterson and Dealy 2014). In addition, by binding to the individual pro- $\alpha 1$ (II) chains and preventing their premature association, $\mathrm{P} 4 \mathrm{H}$ may also act as a chaperone during biosynthesis of procollagen molecules. Procollagen molecules are released from the ER and directed toward secretory pathways following biosynthesis of individual pro- $\alpha 1$ (II) chains, their posttranslational modifications, and folding into triplehelical structure (Chung et al. 2009; Ono et al. 2012). 
Table 1 Skeletal diseases associated with mutations in collagen types II and X

\begin{tabular}{|c|c|c|c|c|c|c|c|}
\hline Disease & Locus & Gene & Inh & Protein & MIM & Main clinical features & Ref. \\
\hline $\begin{array}{l}\text { Hypochondrogenesis, } \\
\text { achondrogenesis type II } \\
\text { (ACG2) }\end{array}$ & $12 \mathrm{q} 13.11$ & COL2A1 & $\mathrm{AD}$ & $\begin{array}{l}\text { Type II } \\
\text { collagen }\end{array}$ & 200610 & $\begin{array}{l}\text { Severe micromelic dwarfism, } \\
\text { incomplete ossification of the } \\
\text { vertebral bodies, disorganization of } \\
\text { the costochondral junction, small } \\
\text { chest, prominent abdomen }\end{array}$ & $\begin{array}{l}\text { Nishimura et al. 2005; } \\
\text { Forzano et al. 2007; } \\
\text { Comstock et al. } \\
2010\end{array}$ \\
\hline $\begin{array}{l}\text { Spondyloepiphyseal dysplasia } \\
\text { congenita (SEDc, SDC) }\end{array}$ & $12 \mathrm{q} 13.11$ & COL2A1 & $\mathrm{AD}$ & $\begin{array}{l}\text { Type II } \\
\text { collagen }\end{array}$ & 183900 & $\begin{array}{l}\text { Disproportionate short stature (short } \\
\text { trunk), abnormal epiphyses, } \\
\text { flattened vertebral bodies, myopia, } \\
\text { and/or retinal degeneration with ret- } \\
\text { inal detachment and cleft palate }\end{array}$ & $\begin{array}{l}\text { Anderson et al. } 1990 \text {; } \\
\text { Donahue et al. } \\
\text { 2003; Nishimura } \\
\text { et al. } 2005\end{array}$ \\
\hline Kniest dysplasia & $12 \mathrm{q} 13.11$ & $C O L 2 A 1$ & $\mathrm{AD}$ & $\begin{array}{l}\text { Type II } \\
\text { collagen }\end{array}$ & 156550 & $\begin{array}{l}\text { Short stature, disproportionate (short } \\
\text { trunk), platyspondyly, lumbar } \\
\text { kyphoscoliosis, coronal vertebral } \\
\text { clefts, hypoplastic pelvic bones, hip } \\
\text { dislocation, delayed epiphyseal } \\
\text { ossification (early), megaepiphyses } \\
\text { (late), narrowing of joint spaces, } \\
\text { limited joint mobility, painful joints }\end{array}$ & $\begin{array}{l}\text { Gilbert-Barnes et al. } \\
\text { 1996; Nishimura } \\
\text { et al. } 2005\end{array}$ \\
\hline $\begin{array}{l}\text { Stickler syndrome type } 1 \\
\text { (arthro-ophthalmopathy) }\end{array}$ & $12 \mathrm{q} 13.11$ & COL2A1 & $\mathrm{AD}$ & $\begin{array}{l}\text { Type II } \\
\text { collagen }\end{array}$ & 108300 & $\begin{array}{l}\text { Clinically and genetically } \\
\text { heterogeneous disorder, } \\
\text { characterized by ocular, auditory, } \\
\text { skeletal, and orofacial abnormalities. } \\
\text { Most forms are characterized by the } \\
\text { eye findings of high myopia, } \\
\text { vitreoretinal degeneration, retinal } \\
\text { detachment, and cataracts. } \\
\text { Additional findings comprise } \\
\text { midline clefting (cleft palate or bifid } \\
\text { uvula), Pierre Robin sequence, flat } \\
\text { midface, sensorineural or } \\
\text { conductive hearing loss, mild } \\
\text { spondyloepiphyseal dysplasia, and } \\
\text { early-onset OA }\end{array}$ & $\begin{array}{l}\text { Nishimura et al. 2005; } \\
\text { Ang et al. } 2007 ; \\
\text { Olavarrieta et al. } \\
\text { 2008; Hoornaert } \\
\text { et al. } 2010\end{array}$ \\
\hline $\begin{array}{l}\text { Platyspondylic lethal skeletal } \\
\text { dysplasia, Torrance type } \\
\text { (PLSD-T) }\end{array}$ & $12 \mathrm{q} 13.11$ & $C O L 2 A 1$ & $\mathrm{AD}$ & $\begin{array}{l}\text { Type II } \\
\text { collagen }\end{array}$ & 151210 & $\begin{array}{l}\text { Decreased ossification of the skull } \\
\text { base, disc-like platyspondyly, short } \\
\text { thin ribs, hypoplastic pelvis with } \\
\text { wide sacrosciatic notches and flat } \\
\text { acetabular roof, short tubular long } \\
\text { bones with metaphyseal cupping }\end{array}$ & $\begin{array}{l}\text { Nishimura et al. 2004; } \\
\text { Zankl et al. } 2005\end{array}$ \\
\hline $\begin{array}{l}\text { Spondyloepimetaphyseal } \\
\text { dysplasia, Strudwick type } \\
\text { (SEMD) }\end{array}$ & $12 \mathrm{q} 13.11$ & $C O L 2 A 1$ & $\mathrm{AD}$ & $\begin{array}{l}\text { Type II } \\
\text { collagen }\end{array}$ & 184250 & $\begin{array}{l}\text { Severe dwarfism, superficially } \\
\text { resembling the Morquio syndrome, } \\
\text { pectus carinatum, and scoliosis } \\
\text { which are usually marked. Cleft } \\
\text { palate and retinal detachment } \\
\text { frequently associated, as in SEDc } \\
\text { (183900). A distinctive radiographic } \\
\text { feature is irregular sclerotic changes, } \\
\text { described as "dappled" in the } \\
\text { metaphyses of the long bones }\end{array}$ & $\begin{array}{l}\text { Sulko et al. 2005; } \\
\text { Shapiro et al. 2006; } \\
\text { Czarny-Ratajczak } \\
\text { et al. } 2009\end{array}$ \\
\hline Spondyloperipheral dysplasia & $12 \mathrm{q} 13.11$ & COL2A1 & $\mathrm{AD}$ & $\begin{array}{l}\text { Type II } \\
\text { collagen }\end{array}$ & 271700 & $\begin{array}{l}\text { Short stature, platyspondyly, mild } \\
\text { biconcave disc (fish-mouth } \\
\text { vertebrae), kyphosis, short ilia, } \\
\text { horizontal acetabulae, flattened } \\
\text { capital femoral epiphyses, } \\
\text { acetabular spurs (infancy), very } \\
\text { short distal phalanges ( } 2 \mathrm{nd}, 3 \mathrm{rd}, 4 \text { th, } \\
\text { 5th), short metacarpals ( } 2 \mathrm{nd}, 3 \mathrm{rd}, \\
\text { 4th, 5th), cone-shaped epiphyses, } \\
\text { brachydactyly "E-like" changes, } \\
\text { short feet, short phalanges, short } \\
\text { metatarsals (4th) }\end{array}$ & $\begin{array}{l}\text { Zankl et al. 2004; } \\
\text { Bedeschi et al. } 2011\end{array}$ \\
\hline
\end{tabular}


Table 1 (continued)

\begin{tabular}{|c|c|c|c|c|c|c|c|}
\hline Disease & Locus & Gene & Inh & Protein & MIM & Main clinical features & Ref. \\
\hline $\begin{array}{l}\text { Czech dysplasia, } \\
\text { spondyloepiphyseal dysplasia } \\
\text { with precocious OA }\end{array}$ & $12 q 13.11$ & COL2A1 & $\mathrm{AD}$ & $\begin{array}{l}\text { Type II } \\
\text { collagen }\end{array}$ & 609162 & $\begin{array}{l}\text { Normal stature, mild platyspondyly, } \\
\text { irregular vertebral endplates, narrow } \\
\text { intervertebral disc spaces, irregular } \\
\text { sclerotic acetabulae, flattened capital } \\
\text { femoral epiphyses, narrow iliac } \\
\text { wings, narrow short femoral neck, } \\
\text { arthralgia, flexion contractures } \\
\text { (knee), osteochondromatosis (knee), } \\
\text { short metacarpals (4th-5th), onset of } \\
\text { joint pain in childhood, waddling } \\
\text { gait, hip replacement in early } \\
\text { adulthood, hearing loss }\end{array}$ & $\begin{array}{l}\text { Hoornaert et al. 2007; } \\
\text { Tzschach et al. } \\
\text { 2008; Matsui et al. } \\
\text { 2009 }\end{array}$ \\
\hline $\begin{array}{l}\text { Avascular necrosis of the femoral } \\
\text { head (ANFH) }\end{array}$ & $12 q 13.11$ & COL2A1 & $\mathrm{AD}$ & $\begin{array}{l}\text { Type II } \\
\text { collagen }\end{array}$ & 608805 & $\begin{array}{l}\text { Patients present with groin pain, onset } \\
\text { of symptoms in 2nd to 5th decades } \\
\text { of life, degeneration of hip joint, } \\
\text { narrowing of joint space, avascular } \\
\text { necrosis/cystic changes/sclerosis of } \\
\text { femoral head, generalized osteopo- } \\
\text { rosis (in some patients), mild scoli- } \\
\text { osis (in some patients) }\end{array}$ & $\begin{array}{l}\text { Liu et al. 2005; } \\
\text { Nishimura et al. } \\
\text { 2005; Su et al. } \\
\text { 2008; Kannu et al. } \\
\text { 2011; Li et al. } 2014\end{array}$ \\
\hline $\begin{array}{l}\text { Legg-Calvé-Perthes disease } \\
\text { (LCPD) }\end{array}$ & $12 \mathrm{q} 13.11$ & COL2A1 & $\mathrm{AD}$ & $\begin{array}{l}\text { Type II } \\
\text { collagen }\end{array}$ & 150600 & $\begin{array}{l}\text { Disease onset between } 6 \text { and } 9 \text { years, } \\
\text { short stature, necrosis of capital } \\
\text { femoral epiphysis, more severe in } \\
\text { females, more frequent in males }\end{array}$ & $\begin{array}{l}\text { Nishimura et al. 2005; } \\
\text { Miyamoto et al. } \\
\text { 2007; Su et al. } \\
\text { 2008; Li et al. } 2014\end{array}$ \\
\hline $\begin{array}{l}\text { Otospondylomegaepiphyseal } \\
\text { dysplasia (OSMED), Nance- } \\
\text { Sweeney chondrodysplasia, } \\
\text { chondrodystrophy with sensori- } \\
\text { neural deafness }\end{array}$ & $12 \mathrm{q} 13.11$ & COL2A1 & $\mathrm{AR}$ & $\begin{array}{l}\text { Type II } \\
\text { collagen }\end{array}$ & 215150 & $\begin{array}{l}\text { Short stature, sensorineural hearing } \\
\text { loss, epiphyseal dysplasia, } \\
\text { premature OA, midface hypoplasia, } \\
\text { increased lumbar lordosis, vertebral } \\
\text { coronal clefts (newborn), enlarged } \\
\text { odontoid (childhood), } \\
\text { platyspondyly (childhood), joint } \\
\text { contractures and pains, enlarged } \\
\text { joints, short hands/ fingers/ } \\
\text { metacarpals, prominent } \\
\text { interphalangeal joints }\end{array}$ & Miyamoto et al. 2005 \\
\hline $\begin{array}{l}\text { Metaphyseal (chondro) dysplasia, } \\
\text { Schmid type (MCDS, MCS) }\end{array}$ & $\begin{array}{r}6 \mathrm{q} 21- \\
22.3\end{array}$ & COL10A1 & $\mathrm{AD}$ & $\begin{array}{l}\text { Type X } \\
\text { collagen }\end{array}$ & 156500 & $\begin{array}{l}\text { Short stature (mild to moderate), adult } \\
\text { height } 130-160 \mathrm{~cm} \text {, mild } \\
\text { platyspondyly, coxa vara, femoral } \\
\text { and tibial bowing, metaphyseal } \\
\text { abnormalities of distal and proximal } \\
\text { femurs/proximal tibiae and fibulae/ } \\
\text { distal radius and ulna, metaphyseal } \\
\text { cupping of proximal phalanges and } \\
\text { metacarpals, waddling gait, leg pain } \\
\text { during childhood }\end{array}$ & $\begin{array}{l}\text { Mäkitie et al. 2005; } \\
\text { Ho et al. 2007; } \\
\text { Mäkitie et al. } 2010\end{array}$ \\
\hline
\end{tabular}

$\mathrm{AD}$ autosomal dominant; $\mathrm{AR}$, autosomal recessive; COL2A1, collagen type II alpha 1; COL10A1, collagen type X alpha 1; OA, osteoarthritis

To date, about 330 records of mutations in collagen type II $\alpha 1$ (COL2A1) that cause chondrodysplasias have been published (Stenson et al. 2009). These mutations alter the gene encoding the $\alpha 1$ chain of procollagen type II causing various types of the disease, which can be lethal, i.e., hypochondro dysplasia or deforming, i.e., spondyloepiphyseal dysplasia congenita (SEDc), Kniest dysplasias, and Stickler syndrome or may appear as mild knee and hip joint diseases (Nishimura et al. 2005; Su et al. 2008; Warman et al. 2011; Arnold and Fertala 2013; Li et al. 2014). The most frequent amino acid substitutions in collagen type II occur at the G position of the G-X-Y triplets; for instance, a G853E (p.G1053E) substitution was found in a patient with a lethal form of SED. Some reports described substitutions in the Y position; for example, cysteine substitutions for arginine residues were found in the $\mathrm{Y}$ positions 75 (p.R275C), 519 (p.R719C), and 789 (p.R989C) in 
patients with a mild form of SED, a mild form of OA, and a severe form of SEDc (Hoornaert et al. 2006; Hintze et al. 2008). Relatively rare mutations comprise substitutions in the X position of the G-X-Y triplets that were found in patients with Stickler syndrome (Table 1) (Richards et al. 2000). For example, Chung et al. (2009) investigated the R992C (p.R1192C) substitution in the X position of a G-X-Y triplet of collagen type II. Corresponding substitution (p.R1147C) originally described in mice represents skeletal abnormalities similar to those seen in patients with SEDc (Donahue et al. 2003). Using a system expressing recombinant collagen type II, Chung et al. (2009) demonstrated that R992C mutant caused aberrant electrophoretic mobility and was characterized by relatively low thermostability and the presence of intramolecular disulfide bonds. Additionally, the expression of aberrant collagen type II was associated with ER stress and increased apoptosis of cells producing the mutant. Furthermore, Jensen et al. (2011) demonstrated the association between excessive intracellular accumulation of the R992C mutant molecules and ER stress using organotypic cartilagelike constructs. Other substitution in collagen type II (R789C, p.R989C) also caused misfolding of mutant molecules, decreased their thermostabilities, promoted excessive intracellular accumulation, and increased apoptosis (Hintze et al. 2008). These results genuinely have shown that beyond the loss of function effect, certain mutations in collagen type II may also cause a gain-of-function, i.e., cytotoxic effect. Moreover, these data contribute to the understanding of the molecular basis of mutations that trigger pathological changes seen at the level of skeletal tissues and suggest that mutations in collagen type II associated with variations of thermostability and disturbance of correct folding of the collagen triple helix apart from the pathological impact on extracellular collagenous framework also alter intracellular processes. More recently, Arita et al. (2015) employed a SED mouse model to analyze the morphology of the growth plate. This model consists of conditional expression of the R992C mutant or the wild type (WT) transgene by using a tetracycline (Tet)modulated promoter, leading to the transgene being switched off in the presence of doxycycline (Dox). Morphological analyses of growth plates from newborn, 2-week-old, 6-week-old, and 10-week-old mice suggest excessive accumulation of collagen type II chains within dilated chondrocytes present in growth plates of mice harboring R992C mutants. The presence of similarly dilated cells was neither observed in WT mice nor mice maintained in Tet-off conditions. A histological study of the tibial growth plates showed aberrations in growth plate organization. In contrast to chondrocytes found in growth plates of WT mice, the columnar organization of chondrocytes in mice harboring R992C mutant was disturbed, alterations being indicated by the presence of disorganized columns. Switching off the expression of the R992C mutant in mice with Dox-regulated promoter maintained in Tet-off conditions resulted in developing growth plates with correctly organized chondrocytes (Fig. 3). Abundant collagen type II deposits were noted in the extracellular spaces of growth plates of WT mice, while in contrast, in mice with the mutation, the extracellular content of collagen type II was significantly reduced and its increased intracellular accumulation was clearly visible. Analysis of Sirius red-stained deposits of collagen fibrils present in the growth plates of WT mice indicated their organized pattern of distribution in the longitudinal septa present between adjacent columns of chondrocytes. By contrast, the collagenous matrix present in the growth plates of the mice harboring collagen type II mutant lacked clear structural continuity, and the longitudinal septa were irregularly thickened. In summary, the studies with transgenic mice have shown that the presence of R992C collagen type II results in skeletal aberrations that include alterations of the linear growth. Aberrant columnar organization of chondrocytes was associated with ER stress, abnormal architecture of collagenous matrix, unusual organization of primary cilia, atypical cell polarization, and reduced proliferation of chondrocytes harboring the mutation. In turn, Liang et al. (2014) constructed a mouse model harboring the p.G1170S mutation in collagen type II. Severe defects in skeletal development (chondrodysplasia phenotype) were observed in homozygotes, but not in heterozygotes. Homozygous fetuses were smaller, with shortened and widened long bones, abnormal scapulae, shapeless pelvises, nonossified middle phalanges, malformed ribcages, and lessmineralized vertebrae. These defects indicate that cartilage shaping was disturbed in mice lacking normal collagen type II and endochondral ossification was slowed. In contrary, skeletons from heterozygotes resembled wild types by appearance. Abnormal features of the skeleton were confirmed at the molecular level as well. Chondrocytes in the resting zones of homozygotes were normally distributed; however, the proliferating zones consisted of fusiform cells decreased in number, aligned transversely and chaotically, while the hypertrophic zone was lost. Proteoglycans, collagen type II, and expression of SOX9 (which regulates the expression of collagen type II) in the growth plate were significantly decreased in homozygotes. The analysis of cultured chondrocytes collected from embryonic cartilage by a confocal microscope showed that mutated type II procollagen in homozygotes assembled into bundles, co-localized with the ER, and was retained intracellularly. Intracellular accumulation resulted in ER distention and ER stress-UPR-apoptosis cascade activation. Additionally, expression of several ER stress-related genes, corresponding to CHOP, total XBP1 (tXBP1), spliced XBP1 (sXBP1), Grp78, ATF4, and ATF6, was upregulated in homozygotes and partly increased in heterozygotes. Cell apoptosis prevented the formation of a hypertrophic zone and disrupted normal chondrogenic signaling pathways. In consequence, in homozygotic mice harboring the p.G1170S mutation, 


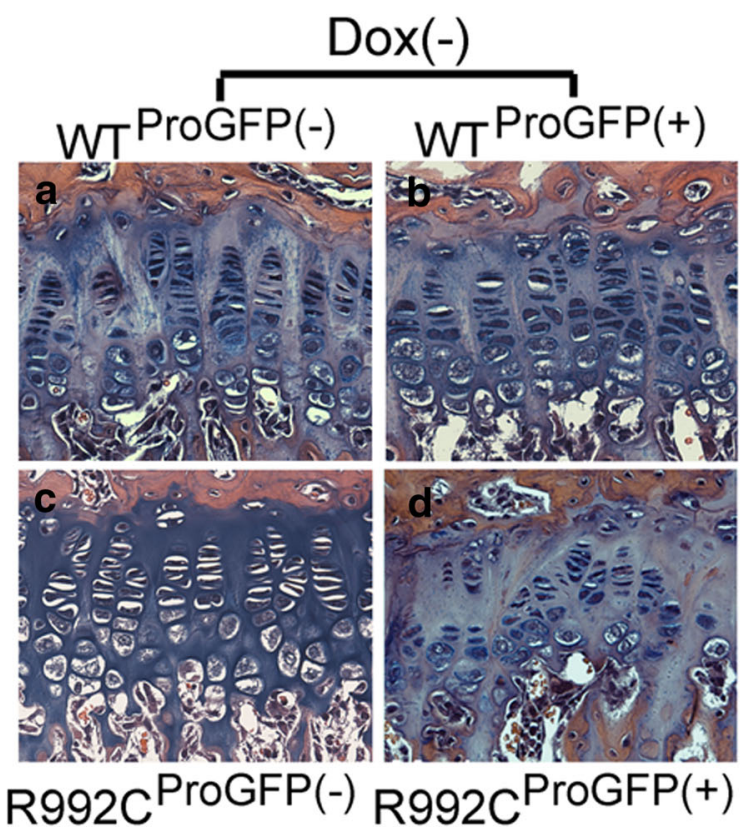

Fig. 3 Histology of the tibial growth plates of the 10-week-old $\mathrm{WT}^{\operatorname{ProGFP}(-)}(\mathbf{a}, \mathbf{e}), \mathrm{WT}^{\operatorname{ProGFP}(+)}(\mathbf{b}, \mathbf{f}), \mathrm{R}^{2} 92 \mathrm{C}^{\operatorname{ProGFP}(-)}(\mathbf{c}, \mathbf{g})$, and $\mathrm{R} 992 \mathrm{C}^{\operatorname{ProGFP}(+)}(D, H)$ mice maintained in the absence $(A-D)$ or presence $(E-H)$ of Dox. In contrast to chondrocytes seen in the growth plates of the 10-week-old $\mathrm{WT}^{\text {ProGFP(-) }}(\mathbf{a}), \mathrm{WT}^{\operatorname{ProGFP}(+)}(\mathbf{b})$, and $\mathrm{R}^{2} 92 \mathrm{C}^{\mathrm{ProGFP}(-)}(\mathbf{c})$ mice, the columnar organization of chondrocytes in the R992 $\mathrm{C}^{\text {ProGFP(+) }}$ littermates was altered (d). For instance, in the R992 $\mathrm{C}^{\operatorname{ProGFP}(+)}$ mice, such alterations were indicated by the presence of disorganized columns whose continuity of the typical palisade-like arrangement was often interrupted

abnormally developed growth plate was found. In contrast, heterozygotes had normal phenotypes with limited ER stress. These results suggest that chondrocytes' death related to ER stress-UPR-apoptosis cascade was a crucial cause of chondrodysplasia.

A novel COL2A1 missense mutation (p.D1469A) in mice was identified, which was situated in the C-propeptide region of $\alpha 1$ chain (Furuichi et al. 2011). Mutation in this position corresponds to human COL2A1 mutation responsible for platyspondylic lethal skeletal dysplasia, Torrance type (PLSD-T). Skeletal defects found in the homozygotes were similar to those in PLSD-T patients. Accumulation of mutant proteins in abnormally expanded rough ER was accompanied by disrupted secretion of this mutant protein into extracellular space and upregulation of ER stress-related genes, corresponding to Grp78 and CHOP in chondrocytes (Table 2).

\section{Mutations in collagen type $X$}

Collagen type $\mathrm{X}$ belongs to non-fibrillar collagens produced by chondrocytes residing within the hypertrophic zone of mammalian growth plates. Each protein chain consists of a carboxyl-terminal non-collagenous domain ( $\mathrm{NC1}$ ), the main

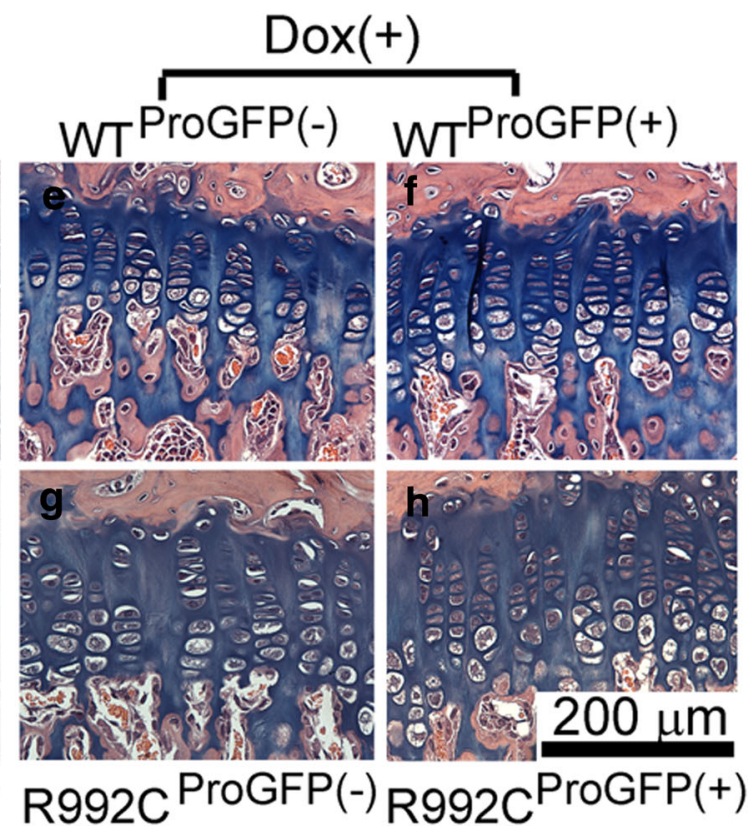

by extended areas in which the chondrocytes were absent (d). Switching off the expression of the R992C ProGFP in the ${ }^{\text {Dox }} \mathrm{R} 992 \mathrm{C}^{\text {ProGFP(+) }}$ mice maintained in Tet-off conditions resulted in developing growth plates in which chondrocytes were organized correctly (h). Growth plates from these mice had a normal morphology comparable to that seen in the ${ }^{\text {Dox }} \mathrm{R} 992 \mathrm{C}^{\text {ProGFP(-) }}$ littermates $(\mathbf{g})$ as well as their ${ }^{\text {Dox }} \mathrm{WT}^{\text {ProGFP( }(-)}$ and ${ }^{\text {Dox }} \mathrm{WT}^{\text {ProGFP(+)}}$ counterparts maintained in Tet-off conditions $(\mathbf{e}, \mathbf{f})$ (reprinted from the American Journal of Pathology (Arita et al. 2015) with permission from Elsevier)

triple-helical domain, an amino-terminal non-collagenous domain (NC2), and a signal peptide. Collagen trimers are stabilized and propagate correctly from the $\mathrm{C}$ - to the $\mathrm{N}$-terminal end of the molecule as a result of potent hydrophobic interactions between the NC1 domains. Missense, nonsense, and frameshift mutations in collagen type $\mathrm{X}$ alpha1 (COL10A1) cause MCDS. Forty of the 42 reported mutations alter the $\mathrm{NC} 1$ domain, whereas two alter the signal peptide cleavage site of the collagen type $X$ protein chain. Both, haploinsufficiency and dominant-negative mechanisms have been reported. Affected individuals are clinically normal at birth, but after they start walking, they develop a disproportionate short stature. The shortening and deformities of the long bones are due to impaired function of the thickened and irregular growth plates (Table 1) (Warman et al. 2011; Mäkitie et al. 2005; Bateman et al. 2003, 2005; Chan et al. 1998).

Several reports of in vitro protein assembly assays, analyses of human MCDS cartilage, as well as transgenic mouse models of MCDS provided evidence that COL10A1 mutations inducing MCDS result in some mRNA degradation, but also determine a gain-of-function effect on the growth plate. For instance, MCDS probant heterozygous for a p.Y663X nonsense mutation produced a truncated $\alpha 1(\mathrm{X})$ chain lacking the last 18 amino acids of the $\mathrm{NC} 1$ domain that 


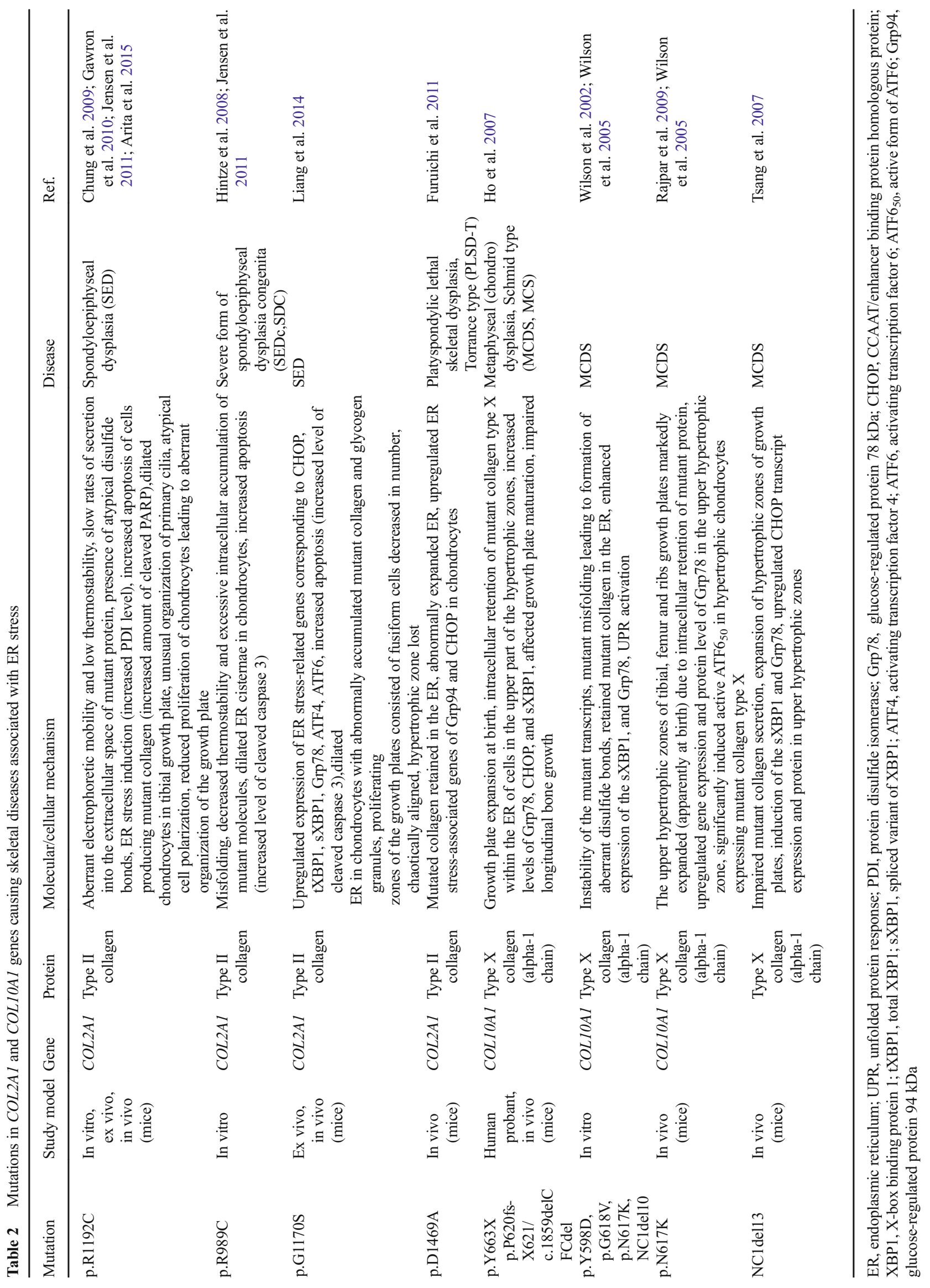


did not form stable homotrimers and were unable to form stable heterotrimers with WT $\alpha 1(\mathrm{X})$ chains. Iliac crest growth plate cartilage from the probant contained $64 \%$ of WT and $36 \%$ of mutant mRNA, and the hypertrophic zone was disorganized and expanded (Ho et al. 2007). In turn, in transgenic FCdel mice corresponding to a human MCDS, p.P620fsX621 mutation showed an early-onset MCDS phenotype with disproportionate shortening of the limbs and coxa vara deformities of the femoral necks. The severity of changes correlated with higher copy numbers/expression of the transgene and increased levels of sXBP1. The FCdel $\alpha 1(\mathrm{X})$ chains that lacked the $\mathrm{C}$-terminal 60 amino acids of the $\mathrm{NC} 1$ domain were synthesized by the $\mathrm{HC}$, but the protein accumulated within the ER. Retention of the FCdel $\alpha 1(\mathrm{X})$ chains was associated, in a concentration-dependent manner, with increased thickness and abnormal maturation of the hypertrophic zone. Thickening of the hypertrophic zones of the FCdel+/- and FCdel+/+ mice, in the absence of endogenous collagen type $\mathrm{X}$, indicated that the retained protein was accompanied by a gain-of-function effect, activating ER stress signaling and affecting growth plate maturation (Ho et al. 2007). Another group constructed mutants predicted either to prohibit subunit folding and assembly (NC1del10 and p.Y598D, respectively) or to allow trimerization and secretion of mutated $\alpha 1(\mathrm{X})$ chains (p.N617K and p.G618V). All four mutations resulted in the formation of aberrant disulfide bonds and significantly increased amounts of BiP, and the sXBP1 mRNA, two key markers of the UPR (Wilson et al. 2002, 2005). In the study of Rajpar et al. (2009), a knock-in mouse model of the COL10A1 (p.N617K) mutation inducing MCDS was generated. It has been demonstrated that the MCDS-associated expanded hypertrophic zone occurred because of disrupted vascular endothelial growth factor (VEGF)- mediated osteoclast erosion of the mineralized cartilage at the vascular invasion front. ER stress and a strong UPR caused by misfolding mutant collagen type $\mathrm{X}$ were key features of the hypertrophic chondrocytes in the MCDS mouse. Furthermore, the targeted stimulation of ER stress in hypertrophic chondrocytes in vivo was sufficient to replicate the MCDS growth plate phenotype functionally, demonstrating the central role played by ER stress in the disease mechanism. Similar results were reported in a MCDS-expressing transgenic mouse line harboring a 13bp deletion in COL10A1 (13del). Mutant collagen type X molecules were accumulated within hypertrophic chondrocytes that underwent ER stress which lead to altered chondrocyte differentiation (Table 2) (Tsang et al. 2007). It is therefore possible, that in vivo interference with the assembly of collagen type $\mathrm{X}$ acts dominantly negative, resulting in poor or no secretion of mutant homotrimers and heterotrimers and reduced amounts of normal collagen type X in the ECM. In the absence of mutant collagen type X in the ECM, the phenotype could be attributed to haploinsufficiency for collagen type X (Chan et al. 1998; Bateman et al. 2003). However, if mutant collagen type X is secreted to the ECM, there could be a dominant-negative effect on structural properties of ECM.

\section{Conclusions and perspectives}

The endoplasmic reticulum is one of the major cellular sites for the synthesis, maturation, and folding of secreted, membrane-bound, and organelle-targeted proteins. Perturbations of ER homeostasis via acceleration of unfolded or misfolded proteins cause a stress condition for this organelle. To deal with it and restore a more favorable folding environment, the ER triggers an evolutionarily conserved signaling cascade, named UPR. In addition to physiological processes, increasing evidence suggests that ER stress is involved in certain groups of diseases, for instance neurodegenerative and metabolic diseases as well as in some malignancies, occurring as a result of protein aggregation. Moreover, an increasing number of reports cite ER stress as a novel mechanistic paradigm of connective tissue diseases caused by mutations in several types of collagens. This refers to mutations in collagen type VI that induce mild to severe phenotype of myopathies and mutations in collagen type IV that are responsible for developing of nephropathies, ocular dysgenesis, brain malformations, or cerebral hemorrhages. More importantly, a significant number of reports from in vitro studies and mice models with skeletal abnormalities corresponding to chondrodysplasias point to ER stress as a mechanism involved in the pathogenesis of these group of diseases.

Chondrodysplasias comprise a wide spectrum of phenotypes predominantly affecting cartilage and bone, from the severe disorders that are perinatally lethal to the milder conditions that are recognized in the postnatal period and childhood. The milder chondrodysplasias are characterized by disproportionate short stature, eye abnormalities, cleft palate, and hearing loss. Treatment is difficult and limited, particularly when the pathological process begins before birth and can affect the entire skeletal system. Additionally, considering potential pleiotropic effects of mutant genes, patients suffering from chondrodysplasias may have complications with central and peripheral nervous system, bone marrow, immune system, kidney, heart, etc.

This review focuses on basic mechanisms of ER stress and its significance in certain variants of chondrodysplasia caused by mutations in collagen types II and X. Regarding collagen type II, the following are discussed: substitutions in the $\mathrm{X}$ position of a G-X-Y triplet that are present with skeletal abnormalities similar to those seen in patients with SEDc; substitutions in the Y position that lead to abnormalities found in patients with a mild form of SED, a mild form of OA, and a severe form of SED; as well as a missense mutation in the $\mathrm{C}$ propeptide region of $\alpha 1$ chain which is associated with PLSD-T. Considering collagen type X, missense, 
nonsense, and frameshift mutations responsible for MCDS have been described on the basis of reports from in vitro protein assembly assays, analyses of human cartilage, as well as transgenic mice models. The retained collagen type II/X mutant proteins caused a gain-of-function effect on the growth plate activating ER stress signaling and affecting growth plate organization with decreased thermostability and excessive intracellular accumulation of mutant molecules leading to apoptosis of cells producing collagen mutants as a hallmark. Taking together, efforts should be undertaken in the future investigations to verify the observations from the studies discussed herein, which showed a significant contribution of the ER stress and associated downstream signaling as a pathogenic mechanism of certain variants of chondrodysplasia. A better understanding of this association would be advantageous in designing preventive strategies, early ameliorative management, and/or perhaps novel therapies of the individuals being at risk of developing skeletal diseases. Such interventions potentially translate into a reduction in health costs associated with musculoskeletal disease.

ACG2, achondrogenesis type II; ATF4, activating transcription factor 4; ATF6, activating transcription factor 6; AS, Alport syndrome; AD, autosomal dominant; AR, autosomal recessive; ANFH, avascular necrosis of the femoral head; bZIP transcription factor, basic leucine zipper; BM, Bethlem myopathy; CNX, calnexin; CRT, calreticulin; CREBH, cAMP response element binding protein $\mathrm{H}$; COMP, cartilage oligomeric matrix protein; $\mathrm{C} / \mathrm{EBP}, \mathrm{CCAAT} /$ enhancer binding protein; CHOP, CCAAT/enhancer binding protein homologous protein; COL2A1, collagen type II $\alpha 1$; COL10A1, collagen type $\mathrm{X} \alpha 1$; DOX, doxycycline; ER, endoplasmic reticulum; ERAD, endoplasmic reticulum-associated degradation system; ERSE, ER stress response element; eIF2 $\alpha$, eukaryotic translation initiation factor $2 \alpha$; ECM, extracellular matrix; Grp78, glucose-regulated protein 78 kDa; Grp94, glucoseregulated protein $94 \mathrm{kDa}$; HSP47, heat shock protein 47; IRE1, inositol-requiring enzyme 1; LCPD, Legg-CalvéPerthes disease; LH, lysyl hydroxylase; MCDS/MCS, metaphyseal (chondro) dysplasia, Schmid type; OASIS, old astrocyte specifically induced substance; OA, osteoarthritis; OI, osteogenesis imperfecta; OSMED, otospondylome gaepiphyseal dysplasia; PLSD-T, platyspondylic lethal skeletal dysplasia, Torrance type; $\mathrm{P} 4 \mathrm{H}$, prolyl-4 hydroxylase; PDI, protein disulfide isomerase; PERK, protein kinase RNA-like endoplasmic reticulum kinase; PQCS, protein quality control system; RIP-regulated liver-specific transcription factor, regulated intramembrane proteolysis; sXBP1, spliced variant of X-box binding protein 1; SEMD, spondyloepimetaphyseal dysplasia, Strudwick type; SED, spondyloepiphyseal dysplasia; SEDc / SDC, spondyloepiphyseal dysplasia congenita; TBMN, thin-basement-membrane nephropathy; tXBP1, total $\mathrm{X}$-box binding protein 1; UPP, ubiquitin proteasome pathway; UCMD, Ullrich congenital muscular dystrophy; UPR, unfolded protein response; UPRE, UPR element; VEGF, vascular endothelial growth factor; WT, wild type; XBP1, X-box binding protein 1 .

Acknowledgments I thank Prof. Andrzej Fertala from the Department of Orthopaedic Surgery, Sidney Kimmel Medical College, TJU, Philadelphia, PA, USA, for the critical comments to this review. I am grateful to Prof. Patrick Venables from the Kennedy Institute, Nuffield Department of Orthopaedics, Rheumatology and Musculoskeletal Sciences, University of Oxford, Oxford, UK, for the constructive notes and the assistance in English proofreading during the preparation of this manuscript.

Open Access This article is distributed under the terms of the Creative Commons Attribution 4.0 International License (http:// creativecommons.org/licenses/by/4.0/), which permits unrestricted use, distribution, and reproduction in any medium, provided you give appropriate credit to the original author(s) and the source, provide a link to the Creative Commons license, and indicate if changes were made.

\section{References}

Alam S, Li Z, Atkinson C, Jonigk D, Janciauskiene S, Mahadeva R (2014) Z $\alpha 1$-antitrypsin confers a proinflammatory phenotype that contributes to chronic obstructive pulmonary disease. Am J Respir Crit Care Med 189(8):909-931

Anderson IJ, Goldberg RB, Marion RW, Upholt WB, Tsipouras P (1990) Spondyloepiphyseal dysplasia congenita: genetic linkage to type II collagen (COL2A1). Am J Hum Genet 46(5):896-901

Anelli T, Sitia R (2008) Protein quality control in the early secretory pathway. EMBO J 27(2):315-327

Ang A, Ung T, Puvanachandra N, Wilson L, Howard F, Ryalls M, Richards A, Meredith S, Laidlaw M, Poulson A, Scott J, Snead M (2007) Vitreous phenotype: a key diagnostic sign in Stickler syndrome types 1 and 2 complicated by double heterozygosity. Am J Med Genet A 143A(6):604-607

Arita M, Fertala J, Hou C, Steplewski A, Fertala A (2015) Mechanisms of aberrant organization of growth plates in conditional transgenic mouse model of spondyloepiphyseal dysplasia associated with the R992C substitution in collagen II. Am J Pathol 185(1):214-229

Arnold WV, Fertala A (2013) Skeletal diseases caused by mutations that affect collagen structure and function. Int J Biochem Cell Biol 45(8): $1556-1567$

Barral JM, Broadley SA, Schaffar G, Hartl FU (2004) Roles of molecular chaperones in protein misfolding diseases. Semin Cell Dev Biol 15(1):17-29

Bartoszewski R, Rab A, Fu L, Bartoszewska S, Collawn J, Bebok Z (2011) CFTR expression regulation by the unfolded protein response. Methods Enzymol 491:3-24

Basha B, Samuel SM, Triggle CR, Ding H (2012) Endothelial dysfunction in diabetes mellitus: possible involvement of endoplasmic reticulum stress? Exp Diabetes Res 2012:481840

Bateman JF, Boot-Handford RP, Lamandé SR (2009) Genetic diseases of connective tissues: cellular and extracellular effects of ECM mutations. Nat Rev Genet 10(3):173-183

Bateman JF, Freddi S, Nattrass G, Savarirayan R (2003) Tissue-specific RNA surveillance? Nonsense-mediated mRNA decay causes collagen X haploinsufficiency in Schmid metaphyseal chondrodysplasia cartilage. Hum Mol Genet 12(3):217-225

Bateman JF, Wilson R, Freddi S, Lamandé SR, Savarirayan R (2005) Mutations of COL10A1 in Schmid metaphyseal chondrodysplasia. Hum Mutat 25(6):525-534

Bedeschi MF, Bianchi V, Gentilin B, Colombo L, Natacci F, Giglio S, Andreucci E, Trespidi L, Acaia B, Furga AS, Lalatta F (2011) 
Prenatal manifestation and management of a mother and child affected by spondyloperipheral dysplasia with a C-propeptide mutation in COL2A1: case report. Orphanet J Rare Dis 6:7

Bernales S, Papa FR, Walter P (2006) Intracellular signaling by the unfolded protein response. Annu Rev Cell Dev Biol 22:487-508

Bodian DL, Chan TF, Poon A, Schwarze U, Yang K, Byers PH, Kwok PY, Klein TE (2009) Mutation and polymorphism spectrum in osteogenesis imperfecta type II: implications for genotype-phenotype relationships. Hum Mol Genet 18(3):463-471

Boot-Handford RP, Briggs MD (2010) The unfolded protein response and its relevance to connective tissue diseases. Cell Tissue Res 339(1):197-211

Briggs MD, Bell PA, Wright MJ, Pirog KA (2015) New therapeutic targets in rare genetic skeletal diseases. Expert Opin Orphan Drugs 3(10):1137-1154

Brown MS, Ye J, Rawson RB, Goldstein JL (2000) Regulated intramembrane proteolysis: a control mechanism conserved from bacteria to humans. Cell 100(4):391-398

Chan D, Weng YM, Graham HK, Sillence DO, Bateman JF (1998) A nonsense mutation in the carboxyl-terminal domain of type $\mathrm{X}$ collagen causes haploinsufficiency in Schmid metaphyseal chondrodysplasia. J Clin Invest 101(7):1490-1499

Chaudhuri TK, Paul S (2006) Protein-misfolding diseases and chaperonebased therapeutic approaches. FEBS J 273(7):1331-1349

Chhabra S, Jain S, Wallace C, Hong F, Liu B (2015) High expression of endoplasmic reticulum chaperone grp94 is a novel molecular hallmark of malignant plasma cells in multiple myeloma. J Hematol Oncol 8:77

Chiribau CB, Gaccioli F, Huang CC, Yuan CL, Hatzoglou M (2010) Molecular symbiosis of CHOP and C/EBP beta isoform LIP contributes to endoplasmic reticulum stress-induced apoptosis. Mol Cell Biol 30(14):3722-3731

Chung HJ, Jensen DA, Gawron K, Steplewski A, Fertala A (2009) R992C (p.R1192C) substitution in collagen II alters the structure of mutant molecules and induces the unfolded protein response. $\mathrm{J}$ Mol Biol 390(2):306-318

Comstock JM, Putnam AR, Sangle N, Lowichik A, Rose NC, Opitz JM (2010) Recurrence of achondrogenesis type 2 in sibs: additional evidence for germline mosaicism. Am J Med Genet A 152A(7): $1822-1824$

Czarny-Ratajczak M, Chrzanowska K, Bieganski T, Sulko J, Baranska D, Kocyla-Karczmarewicz B, Kuszel L, Jakubowski L, Niedzielski K, Kozlowski K (2009) Severe neonatal spondylometaphyseal dysplasia in two siblings. Am J Med Genet A 149A(10):2166-2172

De Palma S, Capitanio D, Vasso M, Braghetta P, Scotton C, Bonaldo P, Lochmüller H, Muntoni F, Ferlini A, Gelfi C (2014) Muscle proteomics reveals novel insights into the pathophysiological mechanisms of collagen VI myopathies. J Proteome Res 13(11):5022-5030

Donahue LR, Chang B, Mohan S, Miyakoshi N, Wergedal JE, Baylink DJ, Hawes NL, Rosen CJ, Ward-Bailey P, Zheng QY, Bronson RT, Johnson KR, Davisson MT (2003) A missense mutation in the mouse Col2a1 gene causes spondyloepiphyseal dysplasia congenita, hearing loss, and retinoschisis. J Bone Miner Res 18(9):1612-1621

Engin F, Hotamisligil GS (2010) Restoring endoplasmic reticulum function by chemical chaperones: an emerging therapeutic approach for metabolic diseases. Diabetes Obes Metab 12(Suppl 2):108-115

Fawcett TW, Martindale JL, Guyton KZ, Hai T, Holbrook NJ (1999) Complexes containing activating transcription factor (ATF)/cAMPresponsive element-binding protein (CREB) interact with the CCAAT/enhancer-binding protein (C/EBP)-ATF composite site to regulate Gadd153 expression during the stress response. Biochem J 339(Pt 1):135-141

Firtina Z, Danysh BP, Bai X, Gould DB, Kobayashi T, Duncan MK (2009) Abnormal expression of collagen IV in lens activates unfolded protein response resulting in cataract. J Biol Chem 284(51): $35872-35884$
Forzano F, Lituania M, Viassolo V, Superti-Furga A, Wildhardt G, Zabel B, Faravelli F (2007) A familial case of achondrogenesis type II caused by a dominant COL2A1 mutation and 'patchy' expression in the mosaic father. Am J Med Genet A 143A(23):2815-2820

Furuichi T, Masuya H, Murakami T, Nishida K, Nishimura G, Suzuki T, Imaizumi K, Kudo T, Ohkawa K, Wakana S, Ikegawa S (2011) ENU-induced missense mutation in the C-propeptide coding region of Col2a1 creates a mouse model of platyspondylic lethal skeletal dysplasia, Torrance type. Mamm Genome 22(5-6):318-328

Gawron K, Jensen DA, Steplewski A, Fertala A (2010) Reducing the effects of intracellular accumulation of thermolabile collagen II mutants by increasing their thermostability in cell culture conditions. Biochem Biophys Res Commun 396(2):213-218

Gilbert-Barnes E, Langer LO Jr, Opitz JM, Laxova R, Sotelo-Arila C (1996) Kniest dysplasia: radiologic, histopathological, and scanning electronmicroscopic findings. Am J Med Genet 63(1):34-45

Gould DB, Marchant JK, Savinova OV, Smith RS, John SW (2007) Col4al mutation causes endoplasmic reticulum stress and genetically modifiable ocular dysgenesis. Hum Mol Genet 16(7):798-807

Ha Y, Liu H, Xu Z, Yokota H, Narayanan SP, Lemtalsi T, Smith SB, Caldwell RW, Caldwell RB, Zhang W (2015) Endoplasmic reticulum stress-regulated CXCR3 pathway mediates inflammation and neuronal injury in acute glaucoma. Cell Death Dis 6:e1900

Hetz C (2012) The unfolded protein response: controlling cell fate decisions under ER stress and beyond. Nat Rev Mol Cell Biol 13(2):89-102

Hintze V, Steplewski A, Ito H, Jensen DA, Rodeck U, Fertala A (2008) Cells expressing partially unfolded R789C/p.R989C type II procollagen mutant associated with spondyloepiphyseal dysplasia undergo apoptosis. Hum Mutat 29(6):841-851

Ho MS, Tsang KY, Lo RL, Susic M, Mäkitie O, Chan TW, Ng VC, Sillence DO, Boot-Handford RP, Gibson G, Cheung KM, Cole WG, Cheah KS, Chan D (2007) COL10A1 nonsense and frameshift mutations have a gain-of-function effect on the growth plate in human and mouse metaphyseal chondrodysplasia type Schmid. Hum Mol Genet 16(10):1201-1215

Hoornaert KP, Dewinter C, Vereecke I, Beemer FA, Courtens W, Fryer A, Fryssira H, Lees M, Müllner-Eidenböck A, Rimoin DL, Siderius L, Superti-Furga A, Temple K, Willems PJ, Zankl A, Zweier C, De Paepe A, Coucke P, Mortier GR (2006) The phenotypic spectrum in patients with arginine to cysteine mutations in the COL2A1 gene. J Med Genet 43(5):406-413

Hoornaert KP, Marik I, Kozlowski K, Cole T, Le Merrer M, Leroy JG, Coucke PJ, Sillence D, Mortier GR (2007) Czech dysplasia metatarsal type: another type II collagen disorder. Eur J Hum Genet 15(12):1269-1275

Hoornaert KP, Vereecke I, Dewinter C, Rosenberg T, Beemer FA, Leroy JG, Bendix L, Bjorck E, Bonduelle M, Boute O, Cormier-Daire V, De Die-Smulders C, et al. (2010) Stickler syndrome caused by COL2A1 mutations: genotype-phenotype correlation in a series of 100 patients. Eur J Hum Genet 18(8):872-880

Hoozemans JJ, van Haastert ES, Eikelenboom P, de Vos RA, Rozemuller JM, Scheper W (2007) Activation of the unfolded protein response in Parkinson's disease. Biochem Biophys Res Commun 354(3): $707-711$

Horwich A (2004) Cell biology: sight at the end of the tunnel. Nature 431(7008):520-522

Hosoi T, Ozawa K (2009) Endoplasmic reticulum stress in disease: mechanisms and therapeutic opportunities. Clin Sci (Lond) 118(1):19-29

Hosoi T, Sasaki M, Miyahara T, Hashimoto C, Matsuo S, Yoshii M, Ozawa K (2008) Endoplasmic reticulum stress induces leptin resistance. Mol Pharmacol 74(6):1610-1619

Hotamisligil GS (2010) Endoplasmic reticulum stress and the inflammatory basis of metabolic disease. Cell 140(6):900-917

Jeanne M, Labelle-Dumais C, Jorgensen J, Kauffman WB, Mancini GM, Favor J, Valant V, Greenberg SM, Rosand J, Gould DB (2012) 
COL4A2 mutations impair COL4A1 and COL4A2 secretion and cause hemorrhagic stroke. Am J Hum Genet 90(1):91-101

Jensen DA, Steplewski A, Gawron K, Fertala A (2011) Persistence of intracellular and extracellular changes after incompletely suppressing expression of the R789C (p.R989C) and R992C (p.R1192C) collagen II mutants. Hum Mutat 32(7):794-805

Jiang HY, Wek SA, McGrath BC, Lu D, Hai T, Harding HP, Wang X, Ron D, Cavener DR, Wek RC (2004) Activating transcription factor 3 is integral to the eukaryotic initiation factor 2 kinase stress response. Mol Cell Biol 24(3):1365-1377

Joshi M, Kulkarni A, Pal JK (2013) Small molecule modulators of eukaryotic initiation factor $2 \alpha$ kinases, the key regulators of protein synthesis. Biochimie 95(11):1980-1990

Kannu P, O'Rielly DD, Hyland JC, Kokko LA (2011) Avascular necrosis of the femoral head due to a novel $\mathrm{C}$ propeptide mutation in COL2A1. Am J Med Genet A 155A(7):1759-1762

Karsenty G (2008) Transcriptional control of skeletogenesis. Annu Rev Genomics Hum Genet 9:183-196

Karsenty G, Kronenberg HM, Settembre C (2009) Genetic control of bone formation. Annu Rev Cell Dev Biol 25:629-648

Kassan M, Galán M, Partyka M, Saifudeen Z, Henrion D, Trebak M, Matrougui K (2012) Endoplasmic reticulum stress is involved in cardiac damage and vascular endothelial dysfunction in hypertensive mice. Arterioscler Thromb Vasc Biol 32(7):1652-1661

Kelley BP, Malfait F, Bonafe L, Baldridge D, Homan E, Symoens S, Willaert A, Elcioglu N, Van Maldergem L, Verellen-Dumoulin C, Gillerot Y, Napierala D, Krakow D, Beighton P, Superti-Furga A, De Paepe A, Lee B (2011) Mutations in FKBP10 cause recessive osteogenesis imperfecta and Bruck syndrome. J Bone Miner Res 26(3): 666-672

Kim I, Xu W, Reed JC (2008) Cell death and endoplasmic reticulum stress: disease relevance and therapeutic opportunities. Nat Rev Drug Discov 7(12):1013-1030

Kondo S, Murakami T, Tatsumi K, Ogata M, Kanemoto S, Otori K, Iseki K, Wanaka A, Imaizumi K (2005) OASIS, a CREB/ATF-family member, modulates UPR signalling in astrocytes. Nat Cell Biol 7(2):186-194

Kuivaniemi H, Tromp G, Prockop DJ (1997) Mutations in fibrillar collagens (types I, II, III, and XI), fibril-associated collagen (type IX), and network-forming collagen (type $\mathrm{X}$ ) cause a spectrum of diseases of bone, cartilage, and blood vessels. Hum Mutat 9(4):300-315

Kuo DS, Labelle-Dumais C, Mao M, Jeanne M, Kauffman WB, Allen J, Favor J, Gould DB (2014) Allelic heterogeneity contributes to variability in ocular dysgenesis, myopathy and brain malformations caused by Col4a1 and Col4a2 mutations. Hum Mol Genet 23(7): $1709-1722$

Li N, Yu J, Cao X, Wu QY, Li WW, Li TF, Zhang C, Cui YX, Li XJ, Yin ZM, Xia XY (2014) A novel p. Gly630Ser mutation of COL2A1 in a Chinese family with presentations of Legg-Calvé-Perthes disease or avascular necrosis of the femoral head. PLoS One 9(6):e100505

Liang G, Lian C, Huang D, Gao W, Liang A, Peng Y, Ye W, Wu Z, Su P, Huang D (2014) Endoplasmic reticulum stress-unfolding protein response-apoptosis cascade causes chondrodysplasia in a col2a1 p.Gly1170Ser mutated mouse model. PLoS One 9(1):e86894

Lin JH, Walter P, Yen TS (2008) Endoplasmic reticulum stress in disease pathogenesis. Annu Rev Pathol 3:399-425

Lisse TS, Thiele F, Fuchs H, Hans W, Przemeck GK, Abe K, Rathkolb B, Quintanilla-Martinez L, Hoelzlwimmer G, Helfrich M, Wolf E, Ralston SH, Hrabé de Angelis M (2008) ER stress-mediated apoptosis in a new mouse model of osteogenesis imperfecta. PLoS Genet 4(2):e7

Liu MQ, Chen Z, Chen LX (2016) Endoplasmic reticulum stress: a novel mechanism and therapeutic target for cardiovascular diseases. Acta Pharmacol Sin 37(4):425-443

Liu YF, Chen WM, Lin YF, Yang RC, Lin MW, Li LH, Chang YH, Jou YS, Lin PY, Su JS, Huang SF, Hsiao KJ, Fann CS, Hwang HW,
Chen YT, Tsai SF (2005) Type II collagen gene variants and inherited osteonecrosis of the femoral head. N Engl J Med 352(22):2294-2301

Mackie EJ, Tatarczuch L, Mirams M (2011) The skeleton: a multifunctional complex organ: the growth plate chondrocyte and endochondral ossification. J Endocrinol 211(2):109-121

Mahdi AA, Rizvi SH, Parveen A (2016) Role of endoplasmic reticulum stress and unfolded protein responses in health and diseases. Indian J Clin Biochem 31(2):127-137

Maor G, Rencus-Lazar S, Filocamo M, Steller H, Segal D, Horowitz M (2013) Unfolded protein response in Gaucher disease: from human to Drosophila. Orphanet J Rare Dis 8:140

Marini JC, Cabral WA, Barnes AM (2010) Null mutations in LEPRE1 and CRTAP cause severe recessive osteogenesis imperfecta. Cell Tissue Res 339(1):59-70

Matsui Y, Michigami T, Tachikawa K, Yamazaki M, Kawabata H, Nishimura G (2009) Czech dysplasia occurring in a Japanese family. Am J Med Genet A 149A(10):2285-2289

Mäkitie O, Susic M, Cole WG (2010) Early-onset metaphyseal chondrodysplasia type Schmid associated with a COL10A1 frameshift mutation and impaired trimerization of wild-type $\alpha 1(\mathrm{X})$ protein chains. J Orthop Res 28(11):1497-1501

Mäkitie O, Susic M, Ward L, Barclay C, Glorieux FH, Cole WG (2005) Schmid type of metaphyseal chondrodysplasia and COL10A1 mutations-findings in 10 patients. Am J Med Genet A 137A(3): 241-248

Minamino T, Komuro I, Kitakaze M (2010) Endoplasmic reticulum stress as a therapeutic target in cardiovascular disease. Circ Res 107(9): 1071-1082

Miyamoto Y, Matsuda T, Kitoh H, Haga N, Ohashi H, Nishimura G, Ikegawa S (2007) A recurrent mutation in type II collagen gene causes Legg-Calvé-Perthes disease in a Japanese family. Hum Genet 121(5):625-629

Miyamoto Y, Nakashima E, Hiraoka H, Ohashi H, Ikegawa S (2005) A type II collagen mutation also results in oto-spondylomegaepiphyseal dysplasia. Hum Genet 118(2):175-178

Nadanaka S, Yoshida H, Sato R, Mori K (2006) Analysis of ATF6 activation in site- 2 protease-deficient Chinese hamster ovary cells. Cell Struct Funct 31(2): 109-116

Nishimura G, Haga N, Kitoh H, Tanaka Y, Sonoda T, Kitamura M, Shirahama S, Itoh T, Nakashima E, Ohashi H, Ikegawa S (2005) The phenotypic spectrum of COL2A1 mutations. Hum Mutat 26(1): 36-43

Nishimura G, Nakashima E, Mabuchi A, Shimamoto K, Shimamoto T, Shimao Y, Nagai T, Yamaguchi T, Kosaki R, Ohashi H, Makita Y, Ikegawa S (2004) Identification of COL2A1 mutations in platyspondylic skeletal dysplasia, Torrance type. J Med Genet 41(1):75-79

Nugent AE, Speicher DM, Gradisar I, McBurney DL, Baraga A, Doane KJ, Horton WE Jr (2009) Advanced osteoarthritis in humans is associated with altered collagen VI expression and upregulation of ER-stress markers Grp78 and bag-1. J Histochem Cytochem 57(10): 923-931

Okada M, Ikegawa S, Morioka M, Yamashita A, Saito A, Sawai H, Murotsuki J, Ohashi H, Okamoto T, Nishimura G, Imaizumi K, Tsumaki N (2015) Modeling type II collagenopathy skeletal dysplasia by directed conversion and induced pluripotent stem cells. Hum Mol Genet 24(2):299-313

Olavarrieta L, Morales-Angulo C, del Castillo I, Moreno F, MorenoPelayo MA (2008) Stickler and branchio-oto-renal syndromes in a patient with mutations in EYA1 and COL2A1 genes. Clin Genet 73(3):262-267

Ono T, Miyazaki T, Ishida Y, Uehata M, Nagata K (2012) Direct in vitro and in vivo evidence for interaction between Hsp47 protein and collagen triple helix. J Biol Chem 287(9):6810-6818 
Patterson SE, Dealy CN (2014) Mechanisms and models of endoplasmic reticulum stress in chondrodysplasia. Dev Dyn 243(7):875-893

Perri ER, Thomas CJ, Parakh S, Spencer DM, Atkin JD (2016) The unfolded protein response and the role of protein disulfide isomerase in neurodegeneration. Front Cell Dev Biol 3:80

Pieri M, Stefanou C, Zaravinos A, Erguler K, Stylianou K, Lapathitis G, Karaiskos C, Savva I, Paraskeva R, Dweep H, Sticht C, Anastasiadou N, Zouvani I, Goumenos D, Felekkis K, Saleem M, Voskarides K, Gretz N, Deltas C (2014) Evidence for activation of the unfolded protein response in collagen IV nephropathies. J Am Soc Nephrol 25(2):260-275

Rajpar MH, McDermott B, Kung L, Eardley R, Knowles L, Heeran M, Thornton DJ, Wilson R, Bateman JF, Poulsom R, Arvan P, Kadler KE, Briggs MD, Boot-Handford RP (2009) Targeted induction of endoplasmic reticulum stress induces cartilage pathology. PLoS Genet 5(10):e1000691

Richards AJ, Baguley DM, Yates JR, Lane C, Nicol M, Harper PS, Scott JD, Snead MP (2000) Variation in the vitreous phenotype of Stickler syndrome can be caused by different amino acid substitutions in the $\mathrm{X}$ position of the type II collagen Gly-X-Y triple helix. Am J Hum Genet 67(5):1083-1094

Ron I, Rapaport D, Horowitz M (2010) Interaction between parkin and mutant glucocerebrosidase variants: a possible link between Parkinson disease and Gaucher disease. Hum Mol Genet 19(19): 3771-3781

Ron D, Walter P (2007) Signal integration in the endoplasmic reticulum unfolded protein response. Nat Rev Mol Cell Biol 8(7):519-529

Rutkowski DT, Kaufman RJ (2004) A trip to the ER: coping with stress. Trends Cell Biol 14(1):20-28

Sano R, Reed JC (2013) ER stress-induced cell death mechanisms. Biochim Biophys Acta 1833(12):3460-3470

Schröder M (2008) Endoplasmic reticulum stress responses. Cell Mol Life Sci 65(6):862-894

Schröder M, Kaufman RJ (2005) The mammalian unfolded protein response. Annu Rev Biochem 74:739-789

Shapiro F, Mulhern H, Weis MA, Eyre D (2006) Rough endoplasmic reticulum abnormalities in a patient with spondyloepimetaphyseal dysplasia with scoliosis, joint laxity, and finger deformities. Ultrastruct Pathol 30(5):393-400

Shen J, Chen X, Hendershot L, Prywes R (2002) ER stress regulation of ATF6 localization by dissociation of BiP/GRP78 binding and unmasking of Golgi localization signals. Dev Cell 3(1):99-111

Sophia Fox AJ, Bedi A, Rodeo SA (2009) The basic science of articular cartilage: structure, composition, and function. Sports Health 1(6): 461-468

Stenson PD, Mort M, Ball EV, Howells K, Phillips AD, Thomas NS, Cooper DN (2009) The Human Gene Mutation Database: 2008 update. Genome Med 1(1):13

Su P, Li R, Liu S, Zhou Y, Wang X, Patil N, Mow CS, Mason JC, Huang D, Wang Y (2008) Age at onset-dependent presentations of premature hip osteoarthritis, avascular necrosis of the femoral head, or Legg-CalvePerthes disease in a single family, consequent upon a p.Gly1170Ser mutation of COL2A1. Arthritis Rheum 58(6):1701-1706

Suh DH, Kim MK, Kim HS, Chung HH, Song YS (2012) Unfolded protein response to autophagy as a promising druggable target for anticancer therapy. Ann N Y Acad Sci 1271:20-32

Sulko J, Czarny-Ratajczak M, Wozniak A, Latos-Bielenska A, Kozlowski K (2005) Novel amino acid substitution in the Yposition of collagen type II causes spondyloepimetaphyseal dysplasia congenita. Am J Med Genet A 137A(3):292-297

Symoens S, Malfait F, D'hondt S, Callewaert B, Dheedene A, Steyaert W, Bächinger HP, De Paepe A, Kayserili H, Coucke PJ (2013) Deficiency for the ER-stress transducer OASIS causes severe recessive osteogenesis imperfecta in humans. Orphanet J Rare Dis 8:154
Szegezdi E, Logue SE, Gorman AM, Samali A (2006) Mediators of endoplasmic reticulum stress-induced apoptosis. EMBO Rep 7(9): 880-885

Takada K, Hirose J, Senba K, Yamabe S, Oike Y, Gotoh T, Mizuta H (2011) Enhanced apoptotic and reduced protective response in chondrocytes following endoplasmic reticulum stress in osteoarthritic cartilage. Int J Exp Pathol 92(4):232-242

Tsang KY, Chan D, Cheslett D, Chan WC, So CL, Melhado IG, Chan TW, Kwan KM, Hunziker EB, Yamada Y, Bateman JF, Cheung KM, Cheah KS (2007) Surviving endoplasmic reticulum stress is coupled to altered chondrocyte differentiation and function. PLoS Biol 5(3):e44

Tsuru A, Imai Y, Saito M, Kohno K (2016) Novel mechanism of enhancing IRE1 $\alpha$-XBP1 signalling via the PERK-ATF4 pathway. Sci Rep 6:24217

Tzschach A, Tinschert S, Kaminsky E, Lusga E, Mundlos S, GraulNeumann LM (2008) Czech dysplasia: report of a large family and further delineation of the phenotype. Am J Med Genet A 146A(14): 1859-1864

Uehara T, Nakamura T, Yao D, Shi ZQ, Gu Z, Ma Y, Masliah E, Nomura Y, Lipton SA (2006) S-nitrosylated protein-disulphide isomerase links protein misfolding to neurodegeneration. Nature 441(7092): 513-517

Ullman E, Fan Y, Stawowczyk M, Chen HM, Yue Z, Zong WX (2008) Autophagy promotes necrosis in apoptosis-deficient cells in response to ER stress. Cell Death Differ 15(2):422-425

Vembar SS, Brodsky JL (2008) One step at a time: endoplasmic reticulum-associated degradation. Nat Rev Mol Cell Biol 9(12): 944-957

Verbeek E, Meuwissen ME, Verheijen FW, Govaert PP, Licht DJ, Kuo DS, Poulton CJ, Schot R, Lequin MH, Dudink J, Halley DJ, de Coo RI, den Hollander JC, Oegema R, Gould DB, Mancini GM (2012) COL4A2 mutation associated with familial porencephaly and smallvessel disease. Eur J Hum Genet 20(8):844-851

Volonghi I, Pezzini A, Del Zotto E, Giossi A, Costa P, Ferrari D, Padovani A (2010) Role of COL4A1 in basement-membrane integrity and cerebral small-vessel disease. The COL4A1 stroke syndrome. Curr Med Chem 17(13):1317-1324

Walter P, Ron D (2011) The unfolded protein response: from stress pathway to homeostatic regulation. Science 334(6059):1081-1086

Warman ML, Cormier-Daire V, Hall C, Krakow D, Lachman R, LeMerrer M, Mortier G, Mundlos S, Nishimura G, Rimoin DL, Robertson S, Savarirayan R, Sillence D, Spranger J, Unger S, Zabel B, Superti-Furga A (2011) Nosology and classification of genetic skeletal disorders: 2010 revision. Am J Med Genet A 155A(5):943-968

Wilson R, Freddi S, Bateman JF (2002) Collagen X chains harboring Schmid metaphyseal chondrodysplasia $\mathrm{NC1}$ domain mutations are selectively retained and degraded in stably transfected cells. J Biol Chem 277(15):12516-12524

Wilson R, Freddi S, Chan D, Cheah KS, Bateman JF (2005) Misfolding of collagen $X$ chains harboring Schmid metaphyseal chondrodysplasia mutations results in aberrant disulfide bond formation, intracellular retention, and activation of the unfolded protein response. J Biol Chem 280(16):15544-15552

Yam GH, Bosshard N, Zuber C, Steinmann B, Roth J (2006) Pharmacological chaperone corrects lysosomal storage in Fabry disease caused by trafficking-incompetent variants. Am J Physiol Cell Physiol 290(4):C1076-C1082

Yang L, Carlson SG, McBurney D, Horton WE (2005) Multiple signals induce endoplasmic reticulum stress in both primary and immortalized chondrocytes resulting in loss of differentiation, impaired cell growth, and apoptosis. J Biol Chem 280(35):31156-31165

Yoshida H (2007a) ER stress and diseases. FEBS J 274(3):630-658

Yoshida H (2007b) Unconventional splicing of XBP-1 mRNA in the unfolded protein response. Antioxid Redox Signal 9(12):2323-2333 
Zankl A, Neumann L, Ignatius J, Nikkels P, Schrander-Stumpel C, Mortier G, Omran H, Wright M, Hilbert K, Bonafe L, Spranger J, Zabel B, Superti-Furga A (2005) Dominant negative mutations in the C-propeptide of COL2A1 cause platyspondylic lethal skeletal dysplasia, Torrance type, and define a novel subfamily within the type 2 collagenopathies. Am J Med Genet A 133A(1):61-67

Zankl A, Zabel B, Hilbert K, Wildhardt G, Cuenot S, Xavier B, HaVinh R, Bonafe L, Spranger J, Superti-Furga A (2004) Spondyloperipheral dysplasia is caused by truncating mutations in the C-propeptide of COL2A1. Am J Med Genet A 129A(2): $144-148$

Zhang H, Nakajima S, Kato H, Gu L, Yoshitomi T, Nagai K, Shinmori H, Kokubo S, Kitamura M (2013) Selective, potent blockade of the IRE1 and ATF6 pathways by 4-phenylbutyric acid analogues. Br J Pharmacol 170(4):822-834

Zhang K, Shen X, Wu J, Sakaki K, Saunders T, Rutkowski DT, Back SH, Kaufman RJ (2006) Endoplasmic reticulum stress activates cleavage of CREBH to induce a systemic inflammatory response. Cell 124(3):587-599 